\title{
Sharing Knowledge Across Generations and Its Impact on Innovation
}

\author{
Paul J. Woodfield ${ }^{1}$ (D), Kenneth Husted ${ }^{2}$ (1) \\ ${ }^{1}$ International Business, Strategy, and Entrepreneurship, Auckland University of Technology, ${ }^{2}$ Management and International Business, University of \\ Auckland \\ Keywords: knowledge management, knowledge conversion, seci model, innovation, winegrowing, traditional industry, knowledge-based view \\ resource-based view, entrepreneurship \\ https://doi.org/10.26813/001c.31022
}

\section{Wine Business Journal}

Vol. 5, Issue 1, 2022

The next generation (NG) is vital to securing a thriving wine industry. We argue that knowledge sharing affects innovation in family winegrowing businesses, and that the NG brings new knowledge to the family business more likely to lead to radical new innovation. This is contrary to the typical view that the senior generation (SG) is the source of all the valuable knowledge, which must be passed on to the NG. As a traditional industry with a large share of family businesses, winegrowing has a heritage of innovation. Individuals in the family business and their ability to innovate over generations is essential for adaption, competitiveness, and ultimately survival. Using Nonaka and Takeuchi's SECI (socialization, externalization, combination, and internalization) model as a lens, we explore the knowledge creation and innovation outcomes of two-way or "bidirectional" knowledge sharing. Through this lens, we seek to understand how knowledge is shared and utilized within an intergenerational family winegrowing business. We then go further by exploring the impact each generation has on innovation, highlighting the NG as a primary source of new knowledge. We conclude with guidelines for managers in family businesses who aspire to improve innovation outcomes by enabling bidirectional knowledge sharing.

\section{Introduction}

Each generation imagines itself to be more intelligent than the one that went before it, and wiser than the one that comes after it. (George Orwell)

The knowledge next generation (NG) members bring to the family business is often overlooked. Rather, the focus tends to be on the incumbent senior generation (SG) in the succession process, who are seen as grooming, mentoring, and nurturing the NG (Boyd et al., 1999; Distelberg \& Schwarz, 2013; LeCounte, 2020; Wang \& Jiang, 2018). Recent studies have flipped this perception by identifying key characteristics of the knowledge base the NG possesses, and how family businesses engage in knowledge sharing from the younger NG to the older SG (Woodfield \& Husted, 2017, 2019). This can be a source of tension during the succession process because the NG has the potential to break existing path dependencies, thus acting as a catalyst for innovation and change within the family business. Our aim is to demystify bidirectional knowledge sharing, and argue that, if managed well, this can be treated as an opportunity rather than a threat to the business.

Like many traditional industries, winegrowing has its roots in family businesses (Stewart, 2010; Woodfield \& Nel, 2012), and offers a rich context for business research (Orth et al., 2007). Specifically, the winegrowing industry has a long history of science and technology innovation, and warrants further investigation as to how knowledge and inno- vation is managed at the firm level (Broccardo \& Zicari, 2020; Woodfield \& Husted, 2017). In the family business literature, attempts have been made to identify practical implications of innovation (Fuetsch \& Suess-Reyes, 2017), often in the context of maintaining continuity across generations (Rondi et al., 2019). At the same time, family firms are often more loss-averse and therefore invest less in $\mathrm{R} \& \mathrm{D}$ than other firms - except in situations where the long-term goals for the family and the firm are aligned (Chrisman \& Patel, 2012). While family businesses have a significant impact economically (International Family Enterprise Research Academy [IFERA], 2003; Pieper et al., 2021), wine business research encourages more investigation into the rich context of family businesses. Moreover, a recent review shows the predominant focus of wine business research journals tends to be marketing, consumer behavior, or tourism (Nave et al., 2021; Weatherbee et al., 2019), while disciplines including entrepreneurship, innovation management, and knowledge management are underrepresented. This gap is further highlighted by recent research on the role of knowledge between generations, which argues that knowledge sharing is bidirectional in family businesses, and can lead to innovative outcomes and change (Woodfield et al., 2017).

Knowledge is a critical enabler of and input to innovation (Nonaka \& von Krogh, 2009). Some knowledge such as scientific or technical knowledge is more conducive for radical innovations, while practice-based knowledge accumulated 
over a long career often relates to incremental improvements to existing products and processes. This paper explores how intergenerational knowledge sharing within family firms leads to knowledge creation, which further influences innovation.

The wine industry has its roots in family businesses, but these now coexist with corporates. Simultaneously, family businesses are becoming more corporate in leadership and governance. We rely on insights that suggest that knowledge sharing in family firms is bidirectional, whereby the SG and their following NG each present valuable knowledge bases that have the potential to generate innovative outcomes and change (Woodfield \& Husted, 2017, 2019). We argue that the NG entering a family business brings invaluable knowledge from formal education, work experience, and acquired knowledge from travel inside and outside their home country. More vital is understanding how this new knowledge can be shared and utilized within the family firm so that innovation and change become a feature of the NG entering the business. We use the SECI (socialization, externalization, combination, and internalization) knowledge conversion model presented by Nonaka and Takeuchi (1995) to analyze and discuss the impact of encouraging bidirectional knowledge sharing in intergenerational family businesses, and how it affects innovation.

\section{Literature review}

\section{The N.Z. Wine Industry}

On the world stage, the N.Z. wine industry remains small; however, its impact is far-reaching. Though it has a short history, it is one of the fastest growing exporters targeting upper-market segments (Morrison \& Rabellotti, 2017). This recent growth is often assigned to the formation of clusters (Dana et al., 2013; Felzensztein et al., 2019), which enabled the introduction of the coopetition model (Crick \& Crick, 2021). The original drivers of this growth were the family businesses of the early 1900s. With their staying power through prohibition, the older family winegrowers were at the forefront of commercialization and introduced innovation to the processes and marketing of wine. Commercializing of the industry occurred on various levels, including the need to produce large quantities of wine, the need to build capacity around education and expertise for viticulturists and winemakers, and building brand awareness and marketing power through both domestic and international channels. These were all important for advancing vineyard practices, winemaking processes, and implementing modern technology through equipment and science (Cooper, 2002). As the winegrowing industry steadily commercialized, family firms became more corporate; that is, with the introduction of new learning, systems, and practices, family firms started to model their corporate counterparts. Throughout the 1960s and into the 1970s, there was an emergence of wineries owned by breweries and liquor companies (for example, McWilliams, Penfolds, and Montana), which reduced the industry to an impersonal market-driven industry (Stewart, 2010). Distinguishing between a family and a corporate winegrower, Stewart (2010) pointedly suggested the following:
Corbans and Montana represented different paths to industrial winemaking. Corbans had grown through traditional winemaking and steady development of wine craft and technology, while Montana had taken the direct route via mass production of gimmick beverages. (p. 323)

With this significant corporate drift, the N.Z. wine industry evolved from the once collaborative and fraternal industry toward the realization that they needed to institutionalize to protect their heritage and future growth. This end of an era meant family estates were now competing against big money and needed to rethink how they would operate going forward. To this end, industry leaders reckoned that the old world formulaic approach was suffocating the creativity and individuality of new world wine:

Commercialization had capsized creativity. District po-
tentials were lost in blending for volume. Environ-
ment-varietal relationships were unassessed. Vinifica-
tion was following a recipe approach. Identifying with
the old world was abandoning the individualism of a
new world. (Corban, 1992, p. 105)

With this pressure to maintain a competitive stance against corporates, family firms needed to innovate to stay ahead of the competition. Although this was happening in some family wineries, there was a need for a common umbrella to forge together the various industry factions and voice a common vision that spurred growth and maintained N.Z.'s winegrowing heritage (Stewart, 2010). In 1975, these factions, including the Wine Council, the Viticultural Association, the Hawkes Bay Grape Growers' Association, and other smaller entities, came together as the Wine Institute of New Zealand, along with the introduction of the Winemakers Levy Act 1976 that allowed levies to be spent on "promotion, development, and organization of the winemaking industry" (New Zealand Government, 1976, Section $9(1)$ ). Now called New Zealand Winegrowers, this institution categorized its membership and is the voice of the winegrowing industry, delivering annual reports on key indicators (Stewart, 2010). The exponential growth of the industry has been maintained since the 1990s; in the year ending 30 June 2020, the industry achieved record exports totaling NZD 1.92 billion, up 6 percent on 2019 (New Zealand Winegrowers, 2020; see Table 1).

Moreover, the New Zealand Institute of Economic Research has measured growth arising from wine $R \& D$, reporting that wine $R \& D$ led to a NZD 41 million increase in exports, a NZD 64.5 million increase in the size of the national economy, and 258 new jobs (New Zealand Institute of Economic Research, 2020). Figure 1 provides an overview of the history of the industry, with key milestones.

\section{Family Businesses}

Family businesses are often underestimated as drivers of the economy (Zachary et al., 2011). A 2007 survey focusing specifically on N.Z. reported that about 70 percent of businesses are family businesses. Of these, over 50 percent were in their first generation, halving for those in their second generation, and halving again for those having reached their third generation (MGI, 2007; Whittaker et al., 2011). 
Table 1. New Zealand wine industry growth, 1990-2020

\begin{tabular}{|c|c|c|c|c|}
\hline Indicator & 1990 & 2010 & 2020 & $\begin{array}{r}\text { Change } \\
(1990-2020)\end{array}$ \\
\hline Number of wineries & 131 & 672 & 717 & $547 \% \uparrow$ \\
\hline Producing area (hectares/acres) & $\begin{array}{r}4880 / \\
12,059\end{array}$ & $\begin{array}{r}33,428 / \\
82,602\end{array}$ & $\begin{array}{r}39,935 / \\
98,682\end{array}$ & $818 \% \uparrow$ \\
\hline Average yield (tonnes per hectare/acre) & $14.4 / 35.6$ & 8/19.8 & 11.4/28.2 & $-21 \% \downarrow$ \\
\hline Tonnes crushed & 70,000 & 266,000 & 457,000 & $653 \% \uparrow$ \\
\hline Wine exports (million liters/gallons) & $4 / 1.1$ & $142 / 37.5$ & $286.5 / 75.7$ & $7,163 \% \uparrow$ \\
\hline Wine exports (NZD million) & 18.4 & 1,041 & 1,923 & $10,451 \% \uparrow$ \\
\hline $\begin{array}{l}\text { Domestic sales of NZ wine (million liters/ } \\
\text { gallons) }\end{array}$ & $39.2 / 10.4$ & $56.7 / 15$ & $50.0 / 13.2$ & $127 \% \uparrow$ \\
\hline Imported wine (million liters/gallons) & $4.5 / 1.2$ & $35.1 / 9.3$ & $41.6 / 10.9$ & $924 \% \uparrow$ \\
\hline Imported wine (NZD million) & 27.8 & 170 (est*) & 204.7 & $736 \% \uparrow$ \\
\hline
\end{tabular}

Source: NZ Winegrowers Annual Reports (Benson-Rea et al., 2011; New Zealand Winegrowers, 2010, 2020). Note: *Import values not reported in 2010 Annual Report.

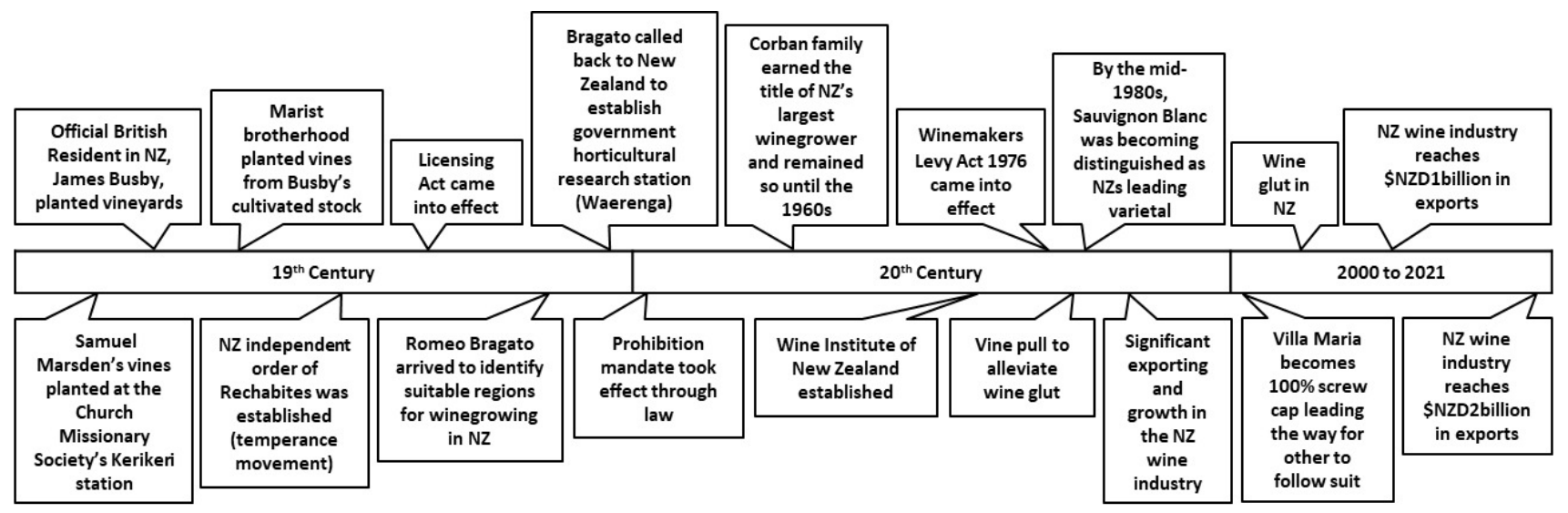

Figure 1. Brief history of the New Zealand wine industry

Even with this decline across generations, family businesses employ half of the workforce and account for 70-90 percent of GDP globally (McKinsey \& Company, 2014; Tharawat, 2016). Their influence on the economy has been noted by consultants, universities, and institutes, who have recognized the need to develop family businesses and their transgenerational viability as a prime concern (Samei \& Feyzbakhsh, 2016; Sharma et al., 2014); for example, by advising family businesses on wealth management, succession planning, and training and advisory services as they navigate complex challenges (KPMG, 2017; PWC, 2018).

There is lack of agreement on a definition of a family business (Rau et al., 2018); here, we are guided by a definition that Payne (2018) highlights as extending the influence of family beyond ownership and management to include its impacts on the business's missions, goals, communication patterns, conflict management, and long-term orientation:

The family business is a business governed and/or managed with the intention to shape and pursue the vision of the business held by a dominant coalition controlled by members of the same family or a small number of families in a manner that is potentially sustainable across generations of the family or families. (Chua et al., 1999, p. 25)
By this definition, nearly all N.Z. winegrowing businesses in the early 1900s (before the industry became corporatized) were family businesses. Currently, about twothirds of small and medium-sized businesses (SMEs) are family businesses (Woodfield, 2012; see Table 2).

\section{Knowledge Management in Family Businesses}

The knowledge-based view (KBV) of the firm, which emerged in the 1990s (Grant, 1996, 2015; Phelps et al., 2012), appropriates the most critical resource under the resource-based view (RBV) - knowledge - and presents it center stage as having "important implications for the creation and sustaining of competitive advantage and for the implementation of strategy through structures and management systems” (Grant, 2015, p. 1). This echoes Drucker's earlier reflections that knowledge had become "the resource, rather than $a$ resource" in relation to "what makes our society" (Drucker, 1993, p. 45, emphasis in original). We embrace the KBV to seek and to understand the content of knowledge sharing between generations. Grant (1996) referred to knowledge as "knowing how with tacit knowledge, and knowing about facts and theories with explicit knowledge," which are distinguished through knowledge trans- 
Table 2. Wine industry categories and typical ownership

\begin{tabular}{|c|c|c|c|c|c|}
\hline Category* & $\begin{array}{l}\text { New Zealand winegrowers } \\
\text { (from 2008) }\end{array}$ & Size & Ownership & Characteristics & Issues \\
\hline \multirow[b]{2}{*}{ One } & \multirow{2}{*}{$\begin{array}{l}\text { Not exceeding 200,000 liters } \\
\text { annually (approx. 53,000 } \\
\text { gallons) }\end{array}$} & $\begin{array}{l}\text { Micro/ } \\
\text { hobby }\end{array}$ & $\begin{array}{l}\text { Individuals or } \\
\text { private companies }\end{array}$ & $\begin{array}{l}\text { - Wine growing as } \\
\text { lifestyle or ego } \\
\text { driven } \\
\text { - Bottling under } \\
\text { contract }\end{array}$ & $\begin{array}{l}\text { - High cost } \\
\text { of } \\
\text { production } \\
\text { - Not } \\
\text { profitable }\end{array}$ \\
\hline & & $\begin{array}{l}\text { Small/ } \\
\text { Boutique }\end{array}$ & $\begin{array}{l}\text { Family run private } \\
\text { companies or } \\
\text { individuals }\end{array}$ & - Export focus & $\begin{array}{l}\text {-Struggle } \\
\text { finding } \\
\text { markets } \\
\text {-Sourcing } \\
\text { grapes } \\
\text {-Strong } \\
\text { competition }\end{array}$ \\
\hline Two & $\begin{array}{l}\text { Between } 200,000 \text { and } \\
4,000,000 \text { liters (approx. } \\
\text { 1,060,000 gallons) }\end{array}$ & Medium & $\begin{array}{l}\text { Private companies } \\
\text { with some foreign } \\
\text { ownership }\end{array}$ & - Quality focus & $\begin{array}{l}\text {-Struggle } \\
\text { with } \\
\text { distribution } \\
\text {-Strong } \\
\text { competition }\end{array}$ \\
\hline Three & Exceeding 4,000,000 liters & Large & $\begin{array}{l}\text { Significant foreign } \\
\text { ownership }\end{array}$ & $\begin{array}{l}\text { - Own capital and } \\
\text { assets } \\
\text { - Use contract } \\
\text { grape growers } \\
\text { - Acquisitions to } \\
\text { increase volume - } \\
\text { Export focus } \\
\text { - Volume focus }\end{array}$ & $\begin{array}{l}\text {-Sourcing } \\
\text { grapes } \\
\text {-Strong } \\
\text { competition }\end{array}$ \\
\hline
\end{tabular}

Source: Coriolis Research (2006); New Zealand Winegrowers (2011, 2020, 2021).

Note: * Based on annual sales.

ferability and mechanisms for transfer across individuals, space, and time (p. 111, emphasis in original). Knowledge management - especially the transferability of knowledge through knowledge sharing - has significance for understanding family business succession (Ge \& Campopiano, 2021), wherein the emphasis is typically on employing the knowledge management perspective to explain the ability for the incumbent SG to pass on tacit, experience-related family business knowledge to the NG. This transfer of knowledge is considered essential for the successful handing over of leadership from one generation to the next (Cabrera-Suárez et al., 2001). However, when transferring of knowledge is not executed well, this poses a serious risk to the continuity and the performance of the business (Daspit et al., 2016). Recent research on innovation in family businesses suggests that, for activities such as innovation and knowledge creation, knowledge flows in both directions in family businesses (Woodfield \& Husted, 2017). This means knowledge flows not only from the SG to the NG but also from the NG to the incumbent SG (see Figure 2). The SG has typically acquired and maintained specific knowledge through trial and error experiences (Sosna et al., 2010). Their accrued knowledge is often displayed as wisdom through intuition and foresight (Aronoff, 1998).

Knowledge held by the NG - in contrast to the tacit, experience-related knowledge of the SG - is often based on explicit, research-based knowledge acquired from university training or firm-specific knowledge from other organizations, which the NG has internalized through their careers outside the family firm.

We use the SECI knowledge conversion model of Nonaka and Takeuchi (1995) to frame our analysis and subsequent

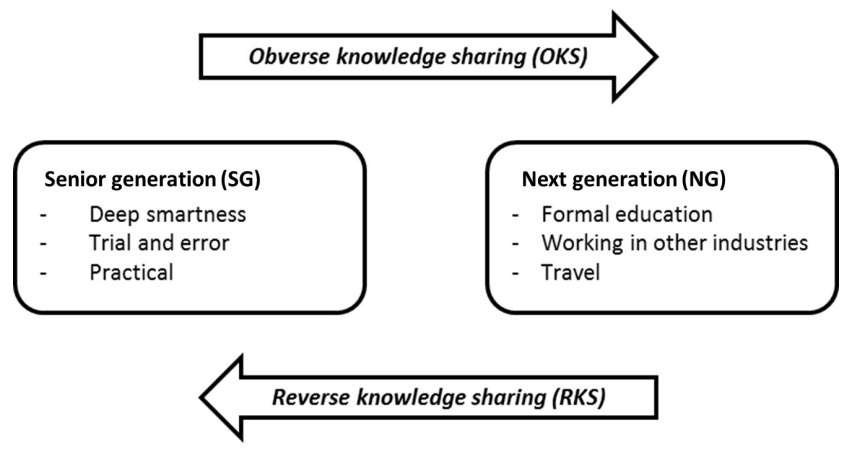

Figure 2. Different knowledge bases and bidirectional flow across generations in a family business

discussion (see Figure 3). The SECI model considers knowledge in two forms: tacit knowledge embedded in an individual experience involving intangible factors including belief, perspective, and values, and explicit knowledge that has been articulated through a language including specifications and manuals. New knowledge is created through the interplay between these two forms of knowledge.

While the SECI model has been utilized across numerous disciplines (Karim et al., 2012; Lievre \& Tang, 2015; Richtnér et al., 2014; Trigo, 2013) and has been used in forming arguments where knowledge creation is a central feature (Hatak \& Roessl, 2015), it is less used in family business research (Ge \& Campopiano, 2021). According to the SECI model, new knowledge is generated from the interplay between tacit and explicit knowledge. This interplay is struc- 
Table 3. Definitions of the SECI model quadrants and relationship to family business

\begin{tabular}{|c|c|c|c|}
\hline $\begin{array}{l}\text { Knowledge } \\
\text { process }\end{array}$ & Conversion & Definition (Nonaka et al., 2000, p. 9-10) & Relationship to family business \\
\hline Socialization & $\begin{array}{l}\text { Tacit to } \\
\text { tacit }\end{array}$ & $\begin{array}{l}\text { "the process of converting new tacit } \\
\text { knowledge through shared experiences. Since } \\
\text { tacit knowledge is difficult to formalize and } \\
\text { often time- and space-specific, tacit knowledge } \\
\text { can be acquired only through shared } \\
\text { experience, such as spending time together or } \\
\text { living in the same environment." }\end{array}$ & $\begin{array}{l}\text { This can be expressed through each } \\
\text { generation learning tacit skills through } \\
\text { observation, imitation, and practice. } \\
\text { Family businesses are a prime example } \\
\text { of where the interaction between } \\
\text { generations is based through shared } \\
\text { experiences and time together. }\end{array}$ \\
\hline Externalization & $\begin{array}{l}\text { Tacit to } \\
\text { explicit }\end{array}$ & $\begin{array}{l}\text { "the process of articulating tacit knowledge } \\
\text { into explicit knowledge. When tacit knowledge } \\
\text { is made explicit, knowledge is crystallized, thus } \\
\text { allowing it to be shared by others, and it } \\
\text { becomes the basis of new knowledge." }\end{array}$ & $\begin{array}{l}\text { Either generation of a family business } \\
\text { could take tacit knowledge and convert } \\
\text { to explicit knowledge as the basis of new } \\
\text { knowledge, so it can be shared with } \\
\text { others. }\end{array}$ \\
\hline Combination & $\begin{array}{l}\text { Explicit to } \\
\text { explicit }\end{array}$ & $\begin{array}{l}\text { "the process of converting explicit knowledge } \\
\text { into more complex and systematic sets of } \\
\text { explicit knowledge. Explicit knowledge is } \\
\text { collected from inside or outside the } \\
\text { organisation and then combined, edited or } \\
\text { processed to form new knowledge." }\end{array}$ & $\begin{array}{l}\text { The conversion of explicit knowledge } \\
\text { into new explicit knowledge can be } \\
\text { exemplified in information being } \\
\text { collected from within a family business } \\
\text { and used for reporting. }\end{array}$ \\
\hline Internalization & $\begin{array}{l}\text { Explicit to } \\
\text { tacit }\end{array}$ & $\begin{array}{l}\text { "the process of embodying explicit knowledge } \\
\text { into tacit knowledge. Through internalization, } \\
\text { explicit knowledge created is shared } \\
\text { throughout an organisation and converted into } \\
\text { tacit knowledge by individuals." }\end{array}$ & $\begin{array}{l}\text { Either generation in a family business } \\
\text { can create explicit knowledge that can } \\
\text { be converted to tacit knowledge } \\
\text { articulated through all language } \\
\text { including specifications and manuals. }\end{array}$ \\
\hline
\end{tabular}

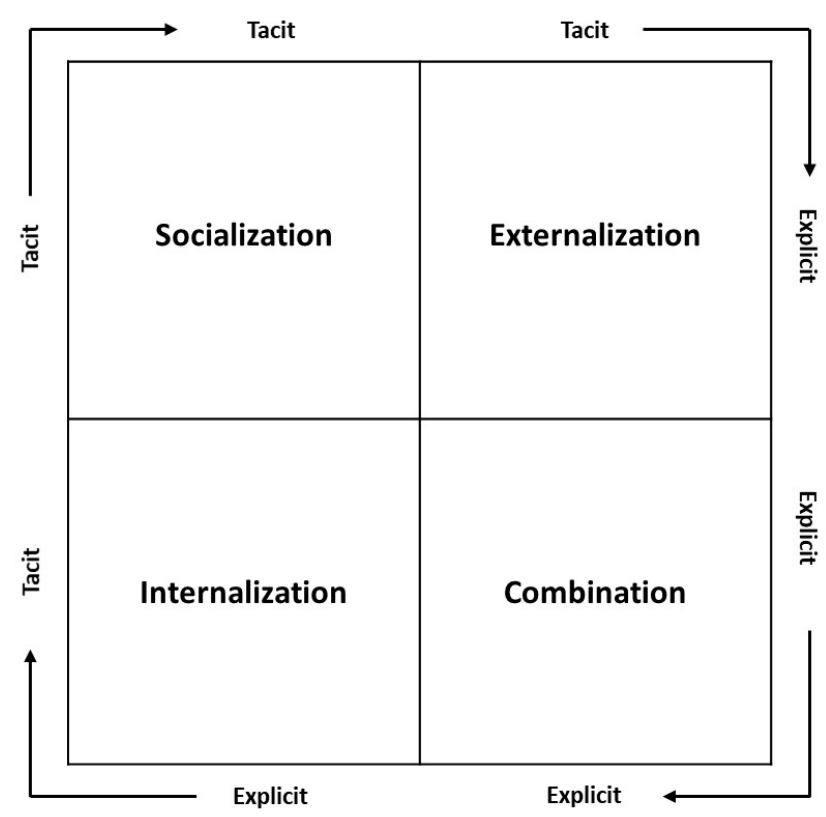

Figure 3. SECI knowledge conversion model (Nonaka \& Takeuchi, 1995)

tured in four knowledge conversion processes - socialization, externalization, combination, and internalization. In Table 3, we provide a summary of the four knowledge conversion processes and elaborate on how these relate to the context of the family business.

\section{Methodology}

Traditional industries such as winegrowing are a rich context for case research (Yin, 2014). The winegrowing in- dustry has several characteristics that provide an innovative environment and render it an appropriate industry to investigate knowledge creation and its relation to innovation outcomes. These characteristics include the broad commodity chain from growing grapes to producing and distributing wine, and the opportunities to create value at various stages in this process. Qualitative studies suit such complex contexts and provide a source for rich explanations of actions and interactions between actors in those contexts (Elsahn et al., 2020).

This study is longitudinal by means of a combined retrospective and real-time analysis (Pettigrew, 1990). While there is no ideal number of cases (Eisenhardt, 1989), a small number of in-depth cases is often acknowledged as avoiding surface-level analysis where a deeper investigation is warranted (Dyer \& Wilkins, 1991; Eisenhardt, 1991). Three case sites were selected, and to minimize perceived biases and doubts inherent in retrospective research, our historical development is based on interviews, observations, and archival evidence (Yin, 2014).

As indicated previously, we are guided by Chua et al.'s (1999) definition of a family business, which provided a way to frame criteria for selecting our cases and interviewees (Kuzel, 1992; Miles \& Huberman, 1994; Patton, 1990) and establishing boundaries for data collection (Merriam \& Tisdell, 2016). The following criteria were followed:

- each case needed at least two generations in the business irrespective of the age of the business;

- the family needed to possess majority control of the business through shareholding, as validated through the New Zealand Companies Register;

- Category 2 wineries as defined by New Zealand Winegrowers (see Table 2);

- the location within N.Z. was not restricted. 
Table 4. Demographic characteristics of interviewees

\begin{tabular}{|c|c|c|c|c|}
\hline $\begin{array}{l}\text { Family participant } \\
\text { (anon) }\end{array}$ & Generation & $\begin{array}{l}\text { Age range (at time of } \\
\text { interview) }\end{array}$ & $\begin{array}{l}\text { Years in business } \\
\text { (approx.) }\end{array}$ & Role \\
\hline \multicolumn{5}{|c|}{$\begin{array}{l}\text { Waitākere Family Vintners - approx. } 100 \text { years old; owned and managed by both the senior and next generation; three generations in } \\
\text { the business since establishment }\end{array}$} \\
\hline A1.1 & $\begin{array}{l}\text { Second } \\
\text { (brother) }\end{array}$ & $65+$ & $60+$ & Executive Director \\
\hline A1.2 & $\begin{array}{l}\text { Second } \\
\text { (brother) }\end{array}$ & $65+$ & $60+$ & Executive Director \\
\hline A1.3 & Second (Sister) & $65+$ & $30-40$ & $\begin{array}{l}\text { Administration } \\
\text { (employee) }\end{array}$ \\
\hline A1.4 & $\begin{array}{l}\text { Third (son of } \\
\text { A1.1) }\end{array}$ & $40-50$ & $20-30$ & CEO \\
\hline A1.5 & $\begin{array}{l}\text { Third (son of } \\
\text { A1.2) }\end{array}$ & $40-50$ & $\leq 5$ & $\begin{array}{l}\text { Principal (not } \\
\text { interviewed) }\end{array}$ \\
\hline
\end{tabular}

Whakatū Family Estates - approx. 50 years old; owned and managed by both the senior and next generation; two generations in the business since establishment

\begin{tabular}{|c|c|c|c|c|}
\hline A2.1 & First (husband) & $50-65$ & $40-50$ & Co-founder \\
\hline A2.2 & First (wife) & $50-65$ & $40-50$ & Co-founder \\
\hline A2.3 & $\begin{array}{l}\text { Second } \\
\text { (daughter) }\end{array}$ & $30-40$ & $20-30$ & Winemaker \\
\hline A2.4 & Second (son) & $30-40$ & $20-30$ & Winemaker \\
\hline A2.5 & $\begin{array}{l}\text { Second } \\
\text { (daughter) }\end{array}$ & $20-30$ & $15-20$ & Marketing \\
\hline
\end{tabular}

In addition to interviewing family members, five employees were interviewed - a Senior Winemaker; Accounts person; two cellar hands; and Administration

\begin{tabular}{|c|c|c|c|c|}
\hline A3.1 & First (husband) & $50-65$ & $40-50$ & Co-founder \\
\hline A3.2 & First (wife) & $50-65$ & $40-50$ & Co-founder \\
\hline A3.3 & $\begin{array}{l}\text { Second } \\
\text { (daughter) }\end{array}$ & $30-40$ & $10-15$ & Marketing \\
\hline A3.4 & Second (son) & $20-30$ & $10-15$ & Managing Director \\
\hline A3.5 & $\begin{array}{l}\text { Second } \\
\text { (daughter) }\end{array}$ & $20-30$ & $\leq 5$ & Managing Director \\
\hline
\end{tabular}

In addition to interviewing family members, five employees were interviewed - a Chief Winemaker; Operations manager Financial manager; Restaurant manager; and Vineyard manager

Our study involved 27 interviews conducted across three family business case sites in the N.Z. wine industry (see Table 4). Initially, a spreadsheet was established of all the wineries sourced from New Zealand Wine annual reports. These wineries were analyzed against the criteria and a proliferation of Category 2 intergenerational winegrowers that were at least two decades old were identified. As part of the elimination process, those who referred to themselves as "family" winegrowers on their websites, books, or through their advertising were included for selection. The shortlist was then discussed with scholars, colleagues, and winegrowers to help narrow down to those that met the criteria and were distinguished enough to gather rich insights. To this end, we followed Pettigrew's (1990) suggestion to choose extreme or polar cases; for example, in terms of demographics such as the age of the business, diverse backgrounds, and having a wine estate in a separate region.
Interviews were carried out with all family members involved in the respective business and a sample of employees to serve as an objective account of the family dynamics. In the first instance, an owner of each firm was engaged to gain the necessary permission to carry out interviews and observations including the nature of the interview. Any additional observations were recorded as field notes, including visits to different parts of the winery; for example, production facilities, vineyards, cellar, or restaurant. Each participant was informed of the research process through a participant information sheet and consent form, which was signed by all interviewees. These were necessary for obtaining permission to record interviews and ensure confidentiality. Anonymity was assured for the companies and the participants, in line with the ethics application and guidelines attached to the research project.

Each case site represents two generations, which allowed for an analysis of knowledge sharing from the SG to the NG 


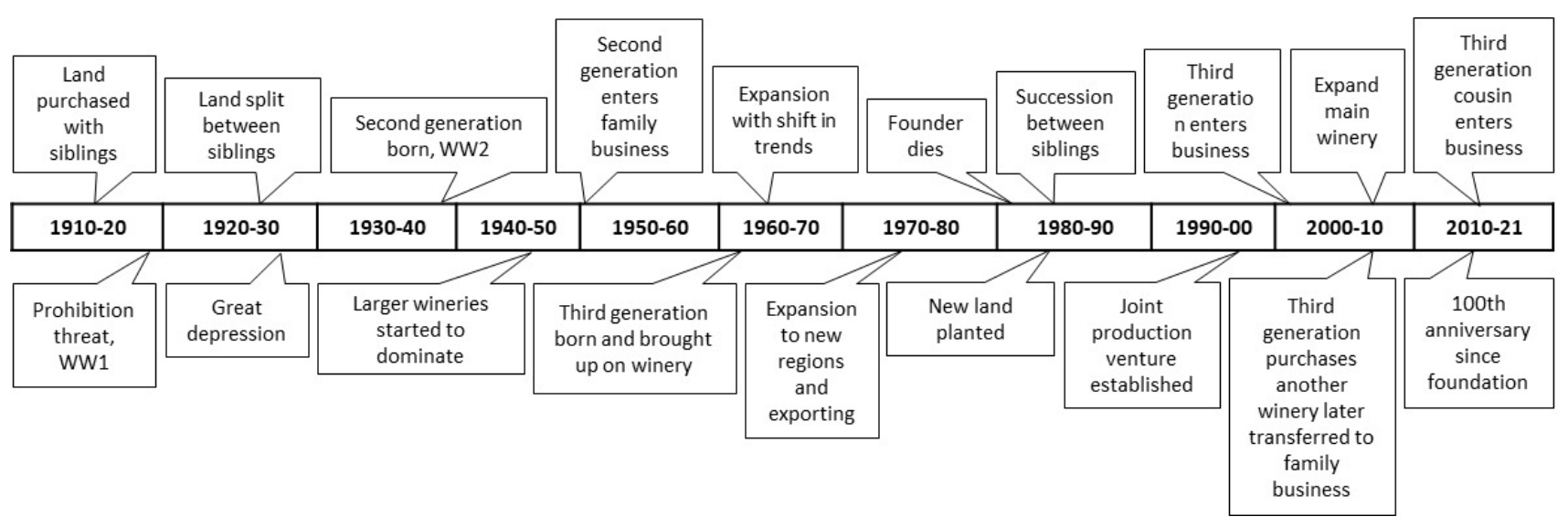

Figure 4. Waitākere Family Vintners brief history (adapted from Woodfield, 2012)

and vice versa. Our case findings are descriptive (De Massis \& Kotlar, 2014) and reflect our aim to analyze and discuss the impact of bidirectional knowledge sharing and how this affects innovation in intergenerational family businesses. Archival evidence provided supported interviews and observations by providing context and historical data from sources such as media, websites, libraries, newspapers, history books, and annual reports. Data including transcripts, field notes, and documents were managed via NVivo qualitative research software, chosen for its search and data management functions. Ultimately, data were analyzed within each family business and across the three family businesses. This enhanced the understanding of scenarios and dynamics for each case site and in turn similarities and differences across the businesses (Miles \& Huberman, 1994).

\section{Case Studies}

Our descriptive case findings demonstrate how valuable the knowledge from each generation is and how the NG knowledge base can drive innovative outcomes and change.

\section{Waitākere Family Vintners}

Established in the early 1900s, Waitākere Family Vintners is the oldest and most experienced of the three winegrowers investigated. By the middle of the 20th century, the founder had called on the second generation to be more involved in the business. The second generation had been working in the vineyards from a very young age and brought a new enthusiasm to what was a very traditionally run business. They brought science and technology to the art of winemaking by following trends such as moving away from fortified wines to table wines and upgrading equipment to make table wine more efficiently.

The third generation brought more formal education and experience into the business, gleaned from working in the corporate world. While the second generation were experienced, they were led by common sense and trial and error. Left by the wayside was an understanding of the potential data that could be gathered from the vineyards and the bottling line. As a rule of thumb, the second generation main- tained about 30 percent debt at any one time; this was considered the measure of success.

The family had been risk averse and lacked insight into how they made money. Although they were successful using their measured approach, this ad hoc practice was formalized and better understood when the third generation joined the business. Lacking was the ability to make informed risks outside of traditional winemaking. With the NG's corporate knowledge, systems and processes were introduced. This brought a sense of professionalism to the family business and enabled a detailed cost of production, which had not been implemented in the past. By moving toward understanding the costs involved in production, the NG was able to understand the risks facing the business, and with this new-found knowledge was able to screen opportunities with confidence as they arose. For example, the NG initiated innovative partnerships including facilities for production and partnerships with chain stores and supermarkets, as well as purchasing other wineries. Moreover, they became inventive with their branding by producing a local wine that spoke to the heart of the community and encouraged nontraditional customers to buy their product. Ultimately, the NG was able to make astute decisions based on information gathered internally (e.g. company finances and products) and externally (new markets), giving fresh foresight to grow the business and leverage new knowledge informing decisions that could lead to innovation outcomes.

\section{Whakatū Family Estates}

Established in the early 1970s, Whakatū Family Estates is known for pioneering the region they have remained in since the inception of their business. With a visionary founder, the pressure was on the NG to bring flair to an already wealthy base of knowledge and finance.

Each of the three children worked in the vineyards and winery from a young age. Like many young adults, they followed their own vocation, entering the business at their own pace. Following his father, the only son chose to be a winemaker first and foremost, and traveled to Australia to gain experience in wineries there. The elder sister studied in a medical profession and the younger sister studied marketing, soon after leaving N.Z. to work abroad. Each of the 


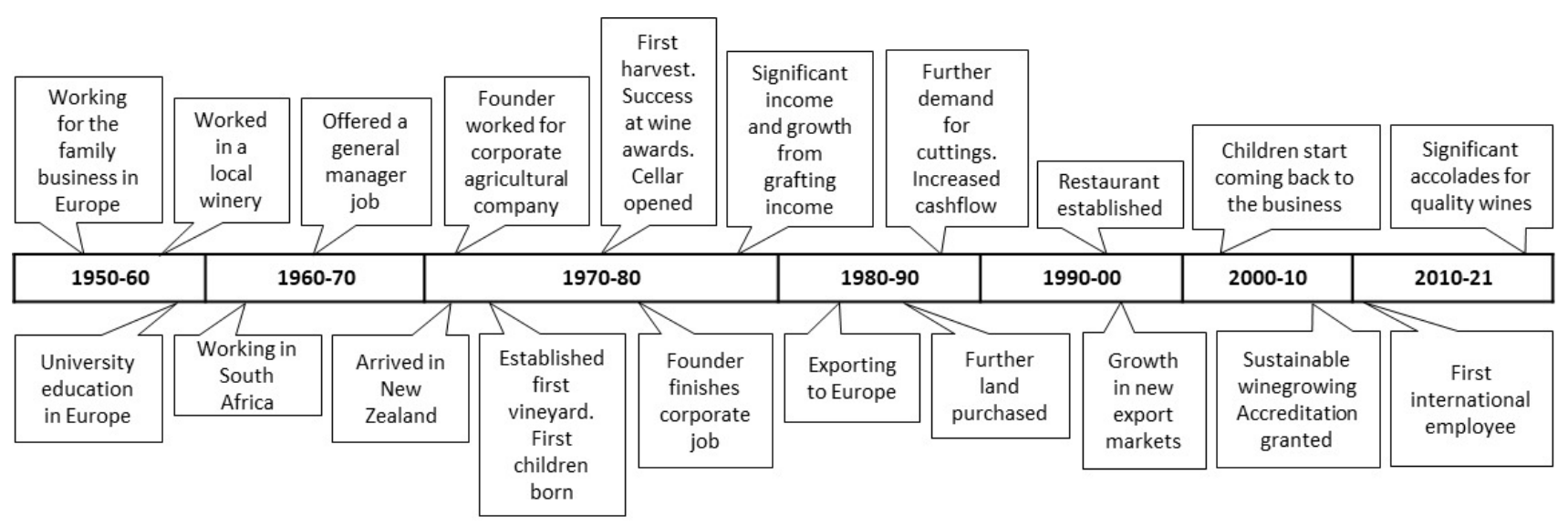

Figure 5. Whakatū Family Estates brief history (adapted from Woodfield, 2012)

sisters referred to their brother as the person with the ideas and the one who would ultimately take responsibility for the business. With each of the children entering the business before they were 30 , the parents still had considerable influence while the children gained experience and started to take responsibility for different functions.

Establishing themselves in the business, the children had more say and were given more freedom to experiment, albeit under the auspices of their parents. The elder daughter, who studied medicine, brought a physiological knowledge alongside her winemaking skills. This knowledge became a point of difference when establishing tasting notes for wines. For example, she had an intimate knowledge of the biochemistry of saliva and the taste centers of the mouth, smell, and how wine affects the body. This expert analysis founded on science heightened the sensory experience that could be shared with customers, which was not limited to describing the taste and aroma through traditional descriptions of fragrances and flavors. This knowledge also contributed to the quality of the wine, which was one of the main aims expressed by the NG. For example, Whakatū Family Winegrowers have gained the highest awards for wine varieties such as Sauvignon Blanc and Gewürztraminer, which were better known as prominent varieties in other regions. This has come about since the second generation entered the business, bringing knowledge from completing vintages elsewhere in N.Z. and overseas. Their wine quality not only put the spotlight on the family's wines, but also their region, driving changes in perceptions regarding the provenance and appellation of N.Z.'s most respected wine varieties.

\section{Tauihu Family Winegrowers}

Originally established as a contract vineyard in the 1970s, Tauihu Family Winegrowers was established as a winery in the late 1980s, with the first harvest in the early 1990s. Although initially a small family business, it was shaped on a corporate business model. The family does not own all the land it grows on, and instead opts to lease land in optimal areas for grapes suiting their style.

The three children had early exposure to the running of the business, particularly the elder daughter, who is a decade older than her siblings. With the founder's astute corporate knowledge of the industry, the business thrived at a time where there was significant growth in the sector. The family carefully balanced growth and debt, but was affected by the wine glut of the early 2000s and later by the global financial crisis. During these plateaux, the older sister - who had trained in hospitality - joined the business to run the estate restaurant. She moved on quickly after an offer from a prominent hotel chain, however, the younger siblings, returning from study and travel, showed interest in the business. Within a decade, they took control of production, management, and future development, with their parents' encouragement. They have complementary skills and experience, with the youngest (a daughter) specializing in viticulture and the second youngest (a son) specializing in winemaking.

The NG recorded notable achievements, including establishing a craft brewery. With an interest in starting something new, the son decided to use winemaking techniques to produce craft beer. This was not initially supported by the family; however, given time and some brewing space, he proved himself with a high-end craft beer that was heavily promoted at international sporting events. Given his foundation in winemaking, to get started, he carried the theme, using wine magnums to bottle the beer and winemaking equipment such as tanks and bottling. With the first seed capital coming from the family and then later from going public to raise capital for a new brewery, the business grew and later plateaued as the N.Z. craft brewing market exploded. Not to be outdone, the younger daughter pushed against barriers within the business, utilizing her organic winegrowing experience. She asked her parents to support her in establishing an organic vineyard that she would control as a separate cost center. Her parents gave her use of part of their landholding to establish a vineyard, which went on to produce award-winning wines and a new revenue stream for the family business.

\section{Results}

Although the selection criteria were the same for each of the case sites (e.g. intergenerational, family with majority control, medium-sized winery), there were differences 


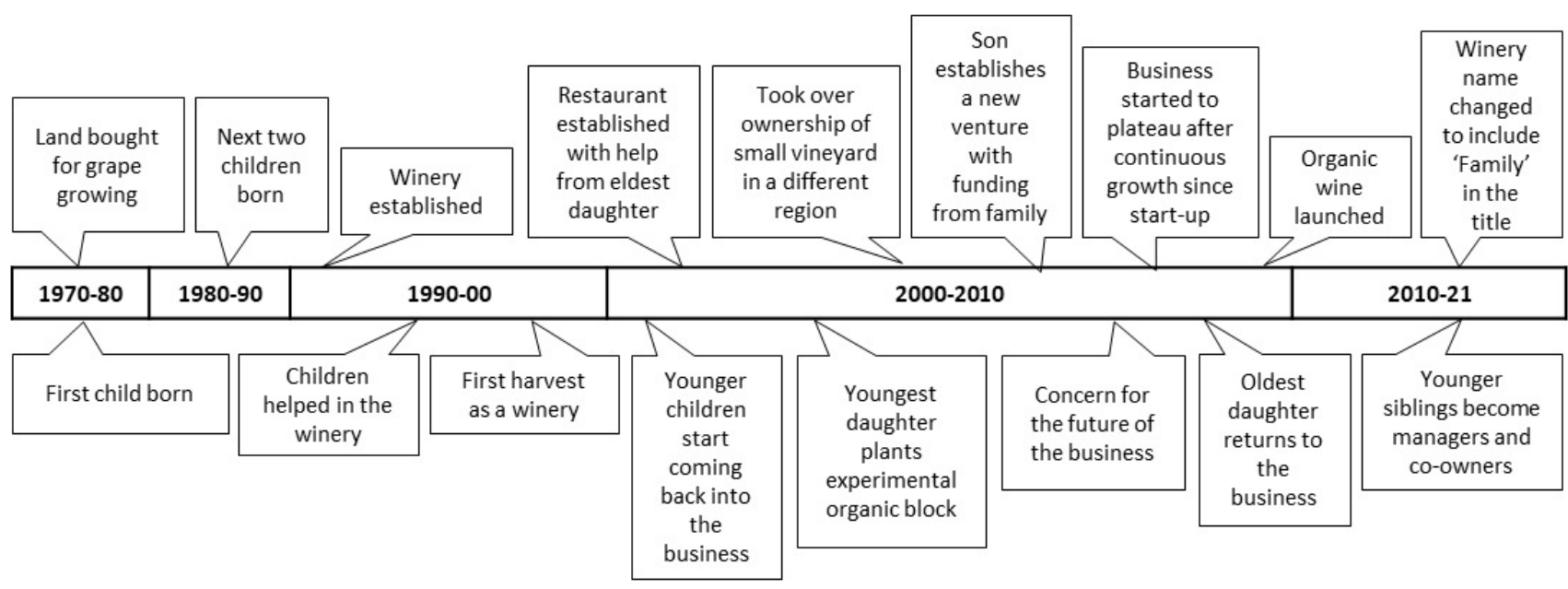

Figure 6. Tauihu Family Winegrowers brief history (adapted from Woodfield, 2012)

in the NG knowledge bases (see Table 5). For example, the NG of Whakatū Family Estates and Tauihu Family Winegrowers entered the business before they were 30 . For Waitākere Family Vintners, the son of one SG brother entered the business in his $40 \mathrm{~s}$, with significant corporate experience, while his cousin with a merchant banking background - the son of the other SG brother - joined at a similar age a decade later. This means that for Waitākere Family Vintners, the NG had significantly more time working outside the wine business and brought a depth of knowledge unmatched by the other two wineries. However, the NG of the two younger firms brought knowledge specific to winemaking, viticulture, and supporting disciplines, such as hospitality and marketing.

\section{Across-Case Findings}

A similarity across the three family businesses was how the NG reflected and extended the entrepreneurial behavior of the SG. With a tendency to share the values of the SG, the NG built on the foundation of the incumbent, typically via process or incremental innovation; for example, the son in Tauihu Family Winegrowers shifted into craft brewing, arguably an extension of winemaking processes. Though the NG came up with new ideas, they were still challenged by the SG and, as a result, at times found it difficult to be entrepreneurial. This perhaps reflects the life stage of when the NG entered the business, at which time, the SG was not ready to step back. For example, when the Whakatū Family Estate's younger daughter wanted to start an organic vineyard, she needed to work through her father's corporate path dependency and the fact that he too was a viticulturist, before being able to prove herself.

Objectively, employees reflected on how they viewed the NG as extending the work of the SG in innovative ways. One employee of Waitākere Family Vintners noticed the shift in dedication to advancing the business when the NG entered the firm. Through formalizing processes and systems, the NG created revenue streams through innovative partnerships and marketing initiatives. The NG also reviewed the family business's core values, and reported and shared these with employees. Employees of Whakatū Family Es- tates observed that the family were pragmatic and had good timing when identifying and exploiting opportunities. Given the SG had built a wealthy foundation, the NG concentrated on innovating through the quality of their wines, to the extent that they won awards for varieties not typical in their region. They also diversified the business by shifting the business model from just producing wine toward contracting out bottling, machinery, and storage, as well as selling their grapes to local wineries and to those in other regions.

In the following section, we examine the impact of intergenerational knowledge sharing on innovation. Then, we discuss the impact each generation has had on innovation through knowledge sharing, before summarizing the innovation opportunities and managerial implications as they relate to the SECI knowledge processes.

\section{Discussion}

With the introduction of the NG, each of the family winegrowing businesses displayed risk taking, innovation, opportunity scanning, and an entrepreneurial orientation (Dominici et al., 2019; Gilinsky et al., 2008; Woodfield et al., 2017). The NG shared their knowledge with the SG, and the SG utilized this by either allowing the NG the freedom to experiment, providing them with seed capital to advance a project, or allowing them to formalize or professionalize systems and processes, which led to changes and innovative outcomes. While winegrowing is a traditional industry, innovation is typically incremental, or process oriented. This is not to say radical or disruptive innovation cannot occur, but rather, that traditional industries are likely to remain "under the radar" in terms of innovation because changes and innovative outcomes are often based on a long-term orientation (Woodfield \& Husted, 2017).

Bidirectional knowledge sharing involving both generations can lead to innovative outcomes when managed to avoid detrimental consequences. Awareness of knowledge sharing as bidirectional can contribute to diverse knowledge representing both generations. Following the SECI model (Nonaka \& Takeuchi, 1995), there are significant opportunities for families to innovate by converting knowl- 
Table 5. Next generation education and experience

\begin{tabular}{|c|c|c|}
\hline $\begin{array}{l}\text { Family } \\
\text { participant } \\
\text { (anon) }\end{array}$ & Generation & Education and experience \\
\hline \multicolumn{3}{|c|}{ Waitākere Family Vintners } \\
\hline $\begin{array}{l}\text { A1.4 } \\
\text { (son of } \\
\text { A1.1) }\end{array}$ & Third & $\begin{array}{l}\text { Brought up in winery; Degree in winemaking and viticulture (Australia); Commerce degree } \\
\text { (marketing and management); worked for family winery for } 2 \text { years after first degree, and } 9 \text { months } \\
\text { after second degree; worked in sales, marketing, and management for pharmaceutical company; } \\
\text { joined family business }\end{array}$ \\
\hline $\begin{array}{l}\text { A1.5 } \\
\text { (son of } \\
\text { A1.2) }\end{array}$ & Third & $\begin{array}{l}\text { Brought up in winery; Bachelor and Masters in Commerce (Finance); Worked for an investment } \\
\text { banking company; joined family business }\end{array}$ \\
\hline \multicolumn{3}{|c|}{ Whakatū Family Estates } \\
\hline $\begin{array}{l}\text { A2.3 } \\
\text { (daughter) }\end{array}$ & Second & $\begin{array}{l}\text { Brought up in winery; Medical degree; Master's degree and vocational training (UK); Post } \\
\text { Graduate Diploma in Viticulture and Oenology; Worked in medicine (Australia, UK, NZ); worked in } \\
\text { wineries in Australia, USA, and Europe; wine internship at a German University; joined family } \\
\text { business }\end{array}$ \\
\hline $\begin{array}{l}\text { A2.4 } \\
\text { (son) }\end{array}$ & Second & $\begin{array}{l}\text { Brought up in winery; Wine science degree (Australia); Owner/manager program; Post Graduate } \\
\text { Diploma in Commerce; worked in wineries in Europe, Australia, and USA; joined the family } \\
\text { business }\end{array}$ \\
\hline $\begin{array}{l}\text { A2.5 } \\
\text { (daughter) }\end{array}$ & Second & $\begin{array}{l}\text { Brought up in winery; Commerce degree (marketing and management); Post Graduate Diploma in } \\
\text { Wine Marketing; (international wine and business); worked in family winery during studies; } \\
\text { marketing experience in Australia; in-store wine tastings for supermarkets and started own } \\
\text { business doing this; worked in high-end cellars; joined family business }\end{array}$ \\
\hline \multicolumn{3}{|c|}{ Tauihu Family Winegrowers } \\
\hline $\begin{array}{l}\text { A3.3 } \\
\text { (daughter) }\end{array}$ & Second & $\begin{array}{l}\text { Helped establish the winery and restaurant; worked for a hotel chain including restaurants; joined } \\
\text { family business to manage the restaurant and cellar door; worked for regional tourism as } \\
\text { marketing manager; rejoined family business as marketing manager/oversees restaurant }\end{array}$ \\
\hline $\begin{array}{l}\text { A3.4 } \\
\text { (son) }\end{array}$ & Second & $\begin{array}{l}\text { Worked in family winery once established; Diploma in Viticulture and Wine Production; worked in } \\
\text { European and USA wineries; joined family business as a winemaker; started a craft brewery using } \\
\text { winemaking methods/equipment (continuing as winemaker); owns/has partnerships in bars }\end{array}$ \\
\hline $\begin{array}{l}\text { A3.5 } \\
\text { (daughter) }\end{array}$ & Second & $\begin{array}{l}\text { Worked in family winery once established; Diploma in Viticulture; worked in wine sales UK for } \\
\text { department store; nanny in the UK; worked in wineries in the USA and NZ; joined family business } \\
\text { as a viticulturist; established organic winegrowing }\end{array}$ \\
\hline
\end{tabular}

Note: See Table 4 for participant labels.

edge by a) retaining their tacit knowledge through socialization via shared experiences, b) gaining new knowledge through externalization, c) combining explicit knowledge gained by the NG, and d) the NG receiving explicit knowledge that can be applied within the family business (see Figure 7).

\section{Senior Generation Impact on Innovation Through Knowledge Sharing}

The SG has greater impact where tacit knowledge is involved. This presents itself in the socialization (tacit $\rightarrow$ tacit) quadrant, and is the essence of an intergenerational family business. Tacit knowledge is expressed through the interaction between the SG and the NG whereby the SG passes on what they know through demonstration, mentoring, grooming, stories, and vision. This provides an environment where tacit knowledge becomes similar across the generations, leading to the creation of values across the family that spur innovation outcomes and change.

Where the SG maintains more impact, but with greater interaction from the NG's explicit knowledge, is through the internalization quadrant (explicit $->$ tacit). In time, the expression of explicit knowledge applied within the family business moves toward becoming tacit knowledge of the firm. For example, the NG of Tauihu Family Winegrowers adapted their formal training and experiences with organic winegrowing into implementing processes within the winery, thus creating change through vineyard practices and new revenue streams.

\section{Next Generation Impact on Innovation Through Knowledge Sharing}

The combination quadrant (explicit -> explicit) has more impact when the NG brings new knowledge and experience to the firm and codifies this within the practices of the family business. For example, the NG of Whakatū Family Estates converted a medical background by adapting physiology knowledge to describe wine. This changed the cellar door experience by incorporating scientific knowledge with traditional tasting notes.

One of the more intriguing findings emerged when considering the externalization quadrant (tacit $\rightarrow$ explicit), which assumes that the NG has tacit knowledge. For example, the NG of Waitākere Family Vintners introduced systems and formalized contracts. Moreover, they procured an assessment of the family values and made these explicit throughout the business, including to employees. This created an enviable environment for innovation and change 


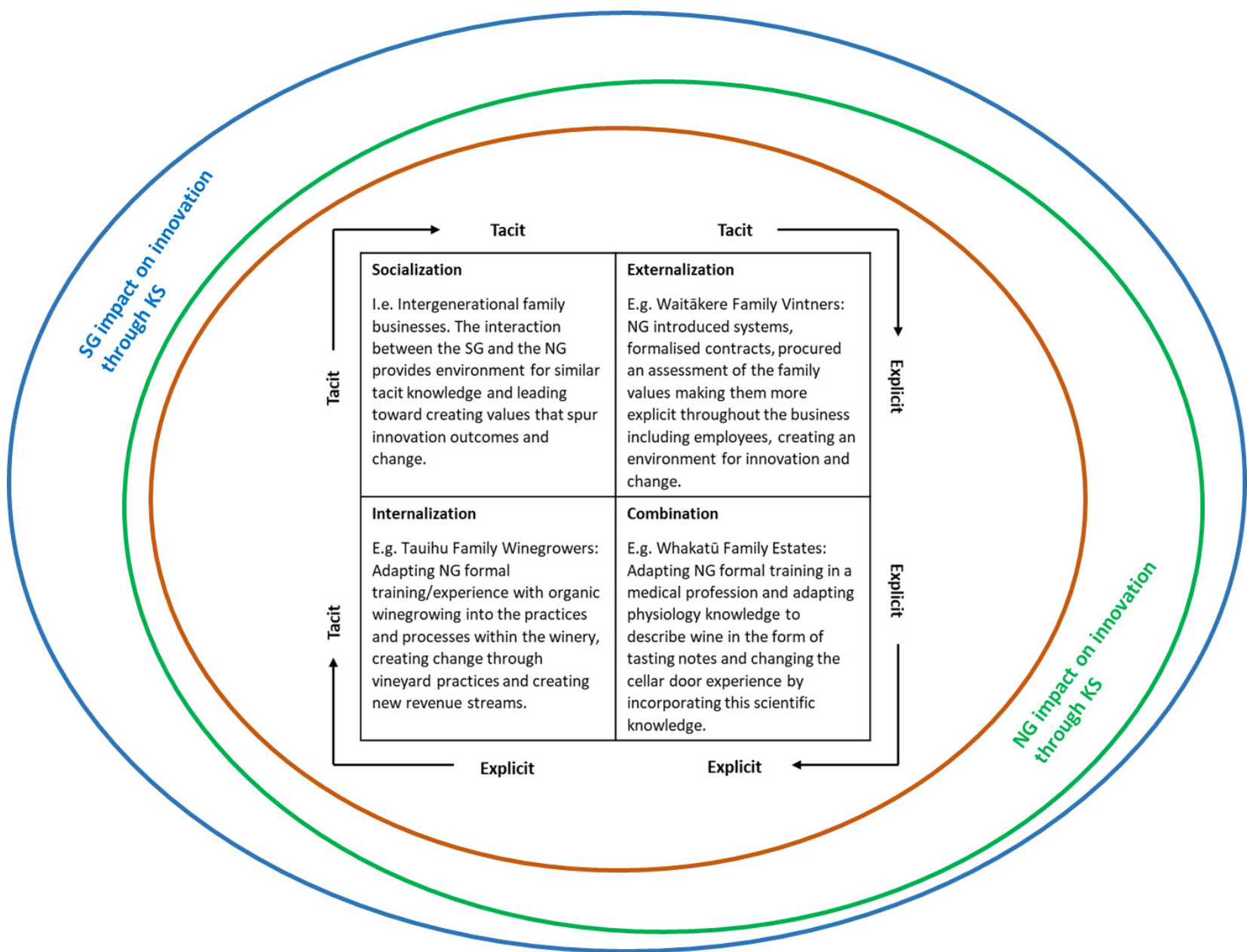

Figure 7. Modified SECI model to reflect the impact of intergenerational knowledge sharing on innovation (Nonaka \& Takeuchi, 1995)

not easily replicated by a non-family business, where stores of tacit knowledge are low because of higher employee turnover. When the NG is brought up in the winery and exposed to business discussions, they can codify the essence of the family values through their systems. Moreover, through the process of formalizing practices, the NG can benchmark enduring family business procedures against external knowledge, which can serve to refine those procedures and validate or "pressure test" new formalized practices as they are integrated with existing practices.

\section{Managerial Implications}

Thus far, we have examined the impact of intergenerational knowledge sharing on innovation - highlighting each generation's impact - through SECI knowledge processes. These are summarized as innovation opportunities endorsed through managerial actions (see Table 6).

Our study shows that there are significant innovation opportunities for families in converting knowledge as part of bidirectional knowledge sharing. The implications for family businesses that blend tacit and explicit knowledge through intergenerational knowledge sharing lie in increased potential for innovation and change. Although anecdotally, families are likely to be aware they possess knowledge that is not easily replicated, they are unlikely to have given thought as to how they might manage bidirectional knowledge across the generations.

However, there is an opportunity for each generation in a family business to "deliberately" manage their knowledge. This can be done via an inventory of the knowledge base (tacit and explicit) and an awareness of how this knowledge can be combined or blended with that of other members of the family. This would allow family members to benchmark the input and impact of their knowledge individually and collectively. Moreover, the way the family manages and governs knowledge can in turn determine more intentional and purposeful outcomes. This deliberate approach is particularly useful when executing the handing over of leadership to the NG. Further, an inventory of knowledge can shape the innovation trajectory of the business through the succession process. Ultimately, managing and governing knowledge across generations bolsters the confidence of both generations when transitioning the business to the NG.

\section{Theoretical Implications}

This study expands our understanding of how bidirectional knowledge sharing in family businesses affects in- 
Table 6. Intergenerational knowledge sharing impact on innovation

\begin{tabular}{|c|c|c|}
\hline $\begin{array}{l}\text { Knowledge } \\
\text { process }\end{array}$ & Innovation opportunity & Managerial action \\
\hline $\begin{array}{l}\text { Socialization } \\
\text { (Tacit }->\text { Tacit) }\end{array}$ & $\begin{array}{l}\text { Incremental improvements of processes through the sharing and } \\
\text { reinterpretation of knowledge from one generation to the next. }\end{array}$ & $\begin{array}{l}\text { Support recreation of } \\
\text { knowledge as part of the } \\
\text { socialization process. } \\
\text { Create family norms for } \\
\text { two-way sharing of } \\
\text { knowledge. }\end{array}$ \\
\hline $\begin{array}{l}\text { Externalization } \\
\text { (Tacit }-> \\
\text { Explicit) }\end{array}$ & $\begin{array}{l}\text { As part of this process knowledge from both generations are articulated and } \\
\text { hence 1) easier to share beyond the family circle and 2) exposed to quality } \\
\text { assurance. This can lead to both incremental and radical innovation in the } \\
\text { wake of debunking family myth. }\end{array}$ & $\begin{array}{l}\text { Guidelines for testing } \\
\text { validity of knowledge. } \\
\text { Make relevant knowledge } \\
\text { available outside the family } \\
\text { circle within the business. }\end{array}$ \\
\hline $\begin{array}{l}\text { Combination } \\
\text { (Explicit -> } \\
\text { Explicit) }\end{array}$ & Radical innovation and potentially new business activities. & $\begin{array}{l}\text { Establish access to a wide } \\
\text { range of external } \\
\text { knowledge sources to } \\
\text { complement internal } \\
\text { knowledge. } \\
\text { Manage innovation process } \\
\text { systematically and } \\
\text { priorities resources } \\
\text { objectively. }\end{array}$ \\
\hline $\begin{array}{l}\text { Internalization } \\
\text { (Explicit -> } \\
\text { Tacit) }\end{array}$ & Incremental improvement of both processes and products. & $\begin{array}{l}\text { Systematic analysis of best } \\
\text { practices. }\end{array}$ \\
\hline
\end{tabular}

novation activities (Woodfield \& Husted, 2019) by considering knowledge sharing a transformation process between tacit and explicit forms of knowledge. The analysis confirms previous findings that the SG primarily contributes to innovation by sharing tacit knowledge (Woodfield \& Husted, 2017). However, by using the SECI model, this paper demonstrates that the SG's sharing of tacit knowledge results in innovation either when it changes from one tacit form to another or when it is transformed to explicit knowledge.

We also find that the sharing of knowledge originating in younger generations can lead to innovation as a result of knowledge being combined or internalized into existing operations of the family firm. Moreover, understanding how bidirectional knowledge sharing affects innovation in family businesses also contributes to explaining how such businesses can maintain a significant economic contribution to the societies in which they are anchored (International Family Enterprise Research Academy [IFERA], 2003; Pieper et al., 2021).

\section{Limitations/Directions for Future Research}

There are two major limitations in this study that could be addressed in future research. The first is that the study centered on one "new world" wine-producing country. There is thus an opportunity to broaden the boundaries to include multiple countries and regions across the new and old worlds of wine. Doing so would give rise to an opportunity to draw comparisons and perhaps pursue a longitudinal study that captures knowledge sharing over time. The second limitation concerns the lack of previous research on knowledge creation within family winegrowing businesses. Studies have concentrated on situations where knowledge is shared within or between clusters (e.g. Dana et al., 2013; Felzensztein et al., 2019) or through coopetition activities (e.g. Crick \& Crick, 2021), which are external to the firm. This perceived limitation indicates an opportunity for future research to draw comparisons between family firms and non-family businesses. One intriguing difference would be comparing the potency of tacit knowledge within each of these firm types, and what effect this might have on combining or internalizing knowledge.

\section{Conclusions}

This paper provides insights into the impact each generation of a family business has on innovation and further highlights the NG as a primary source of new knowledge. One of the more intriguing findings concerns the way in which family knowledge (tacit and explicit) can be made more explicit to employees. This conversion of knowledge not only allows systems and procedures to be introduced but captures the essence of family values and best practices. We are advocates for the knowledge NG members bring to the family business, which has been largely overlooked. By highlighting the impact intergenerational knowledge sharing has on innovation through SECI knowledge processes, we reconcile innovation opportunities and managerial actions that can be taken at various stages of the knowledge creation process. Our hope is to sway researchers and practitioners to go beyond path-dependent norms, toward a perspective of regeneration wherein the NG and their knowledge contribution has the potential to foster radical new innovation.

Submitted: August 09, 2021 PDT, Accepted: December 20, 2021 PDT 
This is an open-access article distributed under the terms of the Creative Commons Attribution 4.0 International License (CCBY-4.0). View this license's legal deed at http://creativecommons.org/licenses/by/4.0 and legal code at http://creativecommons.org/licenses/by/4.0/legalcode for more information. 


\section{References}

Aronoff, C. E. (1998). Megatrends in family business. Family Business Review, 11(3), 181-186. https://doi.or $\mathrm{g} / 10.1111 / \mathrm{j} .1741-6248.1998 .00181 . \mathrm{x}$

Benson-Rea, M., Woodfield, P. J., Brodie, R. J., \& Lewis, N. (2011, June 9). Sustainability in strategy: Maintaining a premium position for New Zealand wine [Paper presentation]. Academy of Wine Business ResearchConference, Bordeaux, France. http://acade myofwinebusiness.com/wp-content/uploads/2011/09/ 53-AWBR2011_Benson-Rea_Woodfield_Brodie_Lewi s.pdf

Boyd, J., Upton, N., \& Wircenski, M. (1999). Mentoring in family firms: A reflective analysis of senior executives' perceptions. Family Business Review, 12(4), 299. https://doi.org/10.1111/j.1741-6248.1999.0029 9.x

Broccardo, L., \& Zicari, A. (2020). Sustainability as a driver for value creation: A business model analysis of small and medium enterprises in the Italian wine sector. Journal of Cleaner Production, 259, Article 120852. https://doi.org/10.1016/j.jclepro.2020.120852

Cabrera-Suárez, M. K., De Saá-Pérez, P., \& GarcíaAlmeida, D. (2001). The succession process from a resource- and knowledge-based view of the family firm. Family Business Review, 14(1), 37-48. https://do i.org/10.1111/j.1741-6248.2001.00037.x

Chrisman, J. J., \& Patel, P. C. (2012). Variations in R\&D investments of family and nonfamily firms: Behavioral agency and myopic loss aversion perspectives. Academy of Management Journal, 55(4), 976-997. https://doi.org/10.5465/amj.2011.0211

Chua, J. H., Chrisman, J. J., \& Sharma, P. (1999). Defining the family business by behavior. Entrepreneurship Theory and Practice, 23(4), 19-39. ht tps://doi.org/10.1177/104225879902300402

Cooper, M. (2002). Wine atlas New Zealand. Hodder Moa Beckett.

Corban, A. (1992). Behind the wine curtain. A. A. Corban and Associates.

Coriolis Research. (2006). An overview of the New Zealand wine industry. Coriolis Research. https://corio lisresearch.com/pdfs/coriolis_overview_new_zealan d_wine industry may2006.pdf

Crick, J. M., \& Crick, D. (2021). Coopetition and familyowned wine producers. Journal of Business Research, 135, 319-336. https://doi.org/10.1016/i.jbusres.202 $\underline{1.06 .046}$

Dana, L.-P., Granata, J., Lasch, F., \& Carnaby, A. (2013). The evolution of co-opetition in the Waipara wine cluster of New Zealand. Wine Economics and Policy, 2(1), 42-49. https://doi.org/10.1016/j.wep.2013.05.00 1

Daspit, J. J., Holt, D. T., Chrisman, J. J., \& Long, R. G. (2016). Examining family firm succession from a social exchange perspective: A multiphase, multistakeholder review. Family Business Review, 29(1), 44-64. https://doi.org/10.1177/0894486515599 $\underline{688}$
De Massis, A., \& Kotlar, J. (2014). The case study method in family business research: Guidelines for qualitative scholarship. Journal of Family Business Strategy, 5(1), 15-29. https://doi.org/10.1016/j.jfbs.20 $\underline{14.01 .007}$

Distelberg, B. J., \& Schwarz, T. V. (2013). Mentoring across family-owned businesses. Family Business Review, 28(3), 193-210. https://doi.org/10.1177/08944 $\underline{86513511327}$

Dominici, A., Boncinelli, F., \& Marone, E. (2019). Lifestyle entrepreneurs in winemaking: An exploratory qualitative analysis on the non-pecuniary benefits [Article]. International Journal of Wine Business Research, 31(3), 385-405. https://doi.org/1 0.1108/ijwbr-06-2018-0024

Drucker, P. (1993). Post-capitalist society. Harper Business.

Dyer, W. G., JR., \& Wilkins, A. L. (1991). Better stories, not better constructs, to generate better theory: A rejoinder to Eisenhardt. Academy of Management Review, 16(3), 613-619. https://doi.org/10.5465/amr.1 $\underline{991.4279492}$

Eisenhardt, K. M. (1989). Building theories from case study research. Academy of Management Review, 14(4), 532-550. https://doi.org/10.5465/amr.1989.4308385

Eisenhardt, K. M. (1991). Better stories and better constructs: The case for rigor and comparative logic. Academy of Management Review, 16(3), 620-627. http s://doi.org/10.5465/amr.1991.4279496

Elsahn, Z., Callagher, L., Husted, K., Korber, S., \& Siedlok, F. (2020). Are rigor and transparency enough? Review and future directions for case studies in technology and innovation management. $R \& D$ Management, 50(3), 309-328. https://doi.org/10.1111/ radm. 12412

Felzensztein, C., Deans, K. R., \& Dana, L. P. (2019). Small firms in regional clusters: Local networks and internationalization in the Southern Hemisphere. Journal of Small Business Management, 57(2), 496-516. https://doi.org/10.1111/jsbm.12388

Fuetsch, E., \& Suess-Reyes, J. (2017). Research on innovation in family businesses: Are we building an ivory tower? Journal of Family Business Management, 7(1), 44-92. https://doi.org/10.1108/ifbm-02-2016-00 $\underline{03}$

Ge, B., \& Campopiano, G. (2021). Knowledge management in family business succession: Current trends and future directions. Journal of Knowledge Management, Advance online publication. https://do i.org/10.1108/jkm-09-2020-0701

Gilinsky, A., Santini, C., Lazzeretti, L., \& Eyler, R. (2008). Desperately seeking serendipity: Exploring the impact of country location on innovation in the wine industry [Article]. International Journal of Wine Business Research, 20(4), 302-320. https://doi.org/1 $\underline{0.1108 / 17511060810919425}$

Grant, R. M. (1996). Toward a knowledge-based theory of the firm. Strategic Management Journal, 17(S2), 109-122. https://doi.org/10.1002/smj.4250171110 
Grant, R. M. (2015). Knowledge-based view. In C. L. Cooper (Ed.), Wiley encyclopedia of management (3rd ed., Vol. 12). John Wiley \& Sons. https://doi.org/10.10 $\underline{02 / 9781118785317 . w e o m 120172}$

Hatak, I. R., \& Roessl, D. (2015). Relational competence-based knowledge transfer within intrafamily succession: an experimental study. Family Business Review, 28(1), 10-25. https://doi.org/10.117 7/0894486513480386

International Family Enterprise Research Academy [IFERA]. (2003). Family businesses dominate: International Family Enterprise Research Academy (IFERA). Family Business Review, 16(4), 235-240. http s://doi.org/10.1177/08944865030160040201

Karim, N. S. A., Razi, M. J. M., \& Mohamed, N. (2012). Measuring employee readiness for knowledge management using intention to be involved with $\mathrm{KM}$ SECI processes. Business Process Management Journal, 18(5), 777-791. https://doi.org/10.1108/14637151211 $\underline{270153}$

KPMG. (2017). European Family Business Barometer: Confidence in unity (6th ed.). https://assets.kpmg/cont ent/dam/kpmg/xx/pdf/2017/11/european-family-busi ness-barometer.pdf

Kuzel, A. J. (1992). Sampling in qualitative inquiry. In B. F. Crabtree \& W. L. Miller (Eds.), Doing qualitative research (pp. 31-44). Sage.

LeCounte, J. F. (2020). Founder-CEOs: Succession planning for the success, growth, and legacy of family firms. Journal of Small Business Management, 1-18. htt ps://doi.org/10.1080/00472778.2020.1725814

Lievre, P., \& Tang, J. (2015). SECI and interorganizational and intercultural knowledge transfer: A case-study of controversies around a project of cooperation between France and China in the health sector. Journal of Knowledge Management, 19(5), 1069-1086. https://doi.org/10.1108/jkm-02-2015-005 $\underline{4}$

McKinsey \& Company. (2014). Perspectives on founderand family-owned businesses. https://www.mckinsey.c om/industries/private-equity-and-principal-investor s/our-insights/perspectives-on-founder-and-family-o wned-businesses

Merriam, S. B., \& Tisdell, E. J. (2016). Qualitative research: A guide to design and implementation (4th ed.). Jossey-Bass.

MGI. (2007). MGI New Zealand family and private business survey. MGI and RMIT. https://www.fambiz.c om.au/wp-content/uploads/06-MGI-New-Zealand-F B-Survey-2007-.pdf

Miles, M. B., \& Huberman, A. M. (1994). Qualitative data analysis. Sage.

Morrison, A., \& Rabellotti, R. (2017). Gradual catch up and enduring leadership in the global wine industry. Research Policy, 46(2), 417-430. https://doi.org/10.101 6/i.respol.2016.09.007

Nave, A., do Paço, A., \& Duarte, P. (2021). A systematic literature review on sustainability in the wine tourism industry: Insights and perspectives. International Journal of Wine Business Research, 33(4), 457-480. htt ps://doi.org/10.1108/IJWBR-09-2020-0046
New Zealand Government. (1976). Winemakers Levy Act 1976. http://www.nzlii.org/nz/legis/hist_act/wmla197 61976n137216/

New Zealand Institute of Economic Research. (2020). Economic impact of research and development in the wine sector: NZIER report to Bragato Research Institute (BRI). https://nzier.org.nz/static/media/filer_public/6 e/67/6e67473b-ba58-48d5-b9e9-2976c9ca6c85/nzie r_economic_impact_report to_bragato_research_instit ute june2020.pdf

New Zealand Winegrowers. (2010). New Zealand Wine Annual Report 2010. https://www.nzwine.com/en/med ia/statistics/annual-report/

New Zealand Winegrowers. (2011). New Zealand Wine Annual Report 2011. https://www.nzwine.com/en/med ia/statistics/annual-report/

New Zealand Winegrowers. (2020). New Zealand Winegrowers Inc Annual Report 2020. https://www.nz wine.com/media/17492/annual-report_2020_final_we b.pdf

New Zealand Winegrowers. (2021). New Zealand Winegrowers Inc Annual Report 2021. https://www.nz wine.com/media/20163/nzw annualreport 2021 fina 1_web_lr.pdf

Nonaka, I., \& Takeuchi, H. (1995). The knowledge creating company: How Japanese companies create the dynamics of innovation. Oxford University Press.

Nonaka, I., Toyama, R., \& Konno, N. (2000). SECI, Ba and leadership: A unified model of dynamic knowledge creation. Long Range Planning, 33(1), 5-34. https://doi.org/10.1016/s0024-6301(99)00115-6

Nonaka, I., \& von Krogh, G. (2009). Tacit knowledge and knowledge conversion: Controversy and advancement in organizational knowledge creation theory. Organization Science, 20(3), 635-652. https://doi.org/ 10.1287/orsc. 1080.0412

Orth, U. R., Lockshin, L., \& d'Hauteville, F. (2007). The global wine business as a research field. International Journal of Wine Business Research, 19(1), 5-13. http s://doi.org/10.1108/17511060710740316

Patton, M. Q. (1990). Qualitative evaluation and research methods. Sage.

Payne, G. T. (2018). Reflections on family business research: Considering domains and theory. Family Business Review, 31(2), 167-175. https://doi.org/10.11 77/0894486518776550

Pettigrew, A. M. (1990). Longitudinal field research on change: Theory and practice. Organization Science, 1(3), 267-292. https://doi.org/10.1287/orsc.1.3.267

Phelps, C., Heidl, R., \& Wadhwa, A. (2012). Knowledge, networks, and knowledge networks: A review and research agenda. Journal of Management, 38(4), 1115-1166. https://doi.org/10.1177/01492063114326 $\underline{40}$

Pieper, T. M., Kellermanns, F. W., \& Astrachan, J. H. (2021). Update 2021: Family businesses' contribution to the U.S. economy. https://familyenterpriseusa.com/w p-content/uploads/2021/02/Family-Businesses-Contri bution-to-the-US-Economy_v.01272021-FINAL_4.pdf 
PWC. (2018). PwC Global Family Business Survey 2018: The values effect. https://www.pwc.com/gx/en/familybusiness-services/assets/pwc-global-family-businesssurvey-2018.pdf

Rau, S. B., Astrachan, J. H., \& Smyrnios, K. X. (2018). The F-PEC revisited: From the family business definition dilemma to foundation of theory. Family Business Review, 31(2), 200-213. https://doi.org/10.11 77/0894486518778172

Richtnér, A., Åhlström, P., \& Goffin, K. (2014). "Squeezing R\&D”: A study of organizational slack and knowledge creation in NPD, using the SECI model. Journal of Product Innovation Management, 31(6), 1268-1290. https://doi.org/10.1111/ipim.12139

Rondi, E., De Massis, A., \& Kotlar, J. (2019). Unlocking innovation potential: A typology of family business innovation postures and the critical role of the family system. Journal of Family Business Strategy, 10(4), Article 100236. https://doi.org/10.1016/j.jfbs.2017.1 $\underline{2.001}$

Samei, H., \& Feyzbakhsh, A. (2016). The effect of mentoring on successor nurturing in family businesses. Journal of Entrepreneurship, 25(2), 211-231. https://doi.org/10.1177/0971355716650370

Sharma, P., Sieger, P., Nason, R. S., González, A. C., \& Ramachandran, K. (Eds.). (2014). Exploring transgenerational entrepreneurship: The role of resources and capabilities. Edward Elgar.

Sosna, M., Trevinyo-Rodríguez, R. N., \& Velamuri, S. R. (2010). Business model innovation through trial-anderror learning: The Naturhouse case. Long Range Planning, 43(2-3), 383-407. https://doi.org/10.1016/ j.lirp.2010.02.003

Stewart, K. (2010). Chancers and visionaries. Random House.

Tharawat. (2016, June 1). Economic impact of family businesses - A compilation of facts. Tharawat Magazine. https://www.tharawat-magazine.com/econ omic-impact-family-businesses/economic-impact-fa mily-businesses-2/

Trigo, A. (2013). Mechanisms of learning and innovation performance: The relevance of knowledge sharing and creativity for non-technological innovation. International Journal of Innovation and Technology Management, 10(6), Article 1340028. https://doi.org/1 $\underline{0.1142 / \mathrm{s} 0219877013400282}$
Wang, X., \& Jiang, M. S. (2018). Learning alongside and learning apart: Successor nurturing styles in family business succession. Knowledge Management Research and Practice, 16(2), 258-266. https://doi.org/10.1080/ 14778238.2018 .1457005

Weatherbee, T. G., Sears, D., \& MacNeil, R. (2019). Mapping wine business research in the International Journal of Wine Business Research: 2007-2017. International Journal of Wine Business Research, 31(4), 591-601. https://doi.org/10.1108/ijwbr-03-2019-0019

Whittaker, H., Fath, B., Fiedler, A., \& Simmons, G. (2011). Growing New Zealand businesses: Summary of survey findings. New Zealand Asia Institute, University of Auckland. https://cdn.auckland.ac.nz/ass ets/business/about/our-research/research-groups/gnz b/2011-gnzb-survey-findings/gnzb-survey-findings-1 5-aug-2011.pdf

Woodfield, P. J. (2012). Intergenerational entrepreneurship in family business: Conceptualising ways entrepreneurial family businesses can be sustained across generations. The University of Auckland. http s://researchspace.auckland.ac.nz/handle/2292/19446

Woodfield, P. J., \& Husted, K. (2017). Intergenerational knowledge sharing in family firms: Case-based evidence from the New Zealand wine industry. Journal of Family Business Strategy, 8(1), 57-69. https://doi.or g/10.1016/j.jfbs.2017.01.001

Woodfield, P. J., \& Husted, K. (2019). How does knowledge sharing across generations impact innovation? International Journal of Innovation Management, 23(8), 17. https://doi.org/10.1142/s1363 $\underline{919619400048}$

Woodfield, P. J., \& Nel, P. (2012). Investing niche wine marketing in New Zealand. International Retail and Marketing Review, 8(1), 24-37. https://doi.org/10.1052 0/EJC123918

Woodfield, P. J., Shepherd, D., \& Woods, C. (2017). How can family winegrowing businesses be sustained across generations? International Journal of Wine Business Research, 29(2). https://doi.org/10.1108/ijwb r-12-2015-0052

Yin, R. K. (2014). Case study research: Design and methods (5th ed.). Sage.

Zachary, R. K., Rogoff, E. G., \& Phinisee, I. (2011). Defining and identifying family entrepreneurship: A new view of entrepreneurs. In M. Minniti (Ed.), The dynamics of entrepreneurship: Evidence from Global Entrepreneurship Monitor data. Oxford Scholarship Online. https://doi.org/10.1093/acprof:oso/97801995 80866.003.0004 